Chapter 5

Sita Steckel

Westfälische Wilhelms-Universität, Münster

\title{
Between censorship and patronage: Interaction between bishops and scholars in Carolingian book dedications
}

\section{Introduction: Carolingian bishops as 'censors'?}

At first glance, it does not seem controversial to state that bishops in Carolingian Francia in the late eighth and ninth centuries frequently received dedications of books and acted as censors of doctrinal writings. In addition to presiding at church councils, bishops had been responsible for overseeing new writings since late antiquity. And though Carolingian kings played an important role in initiating and controlling ecclesiastical reform, it was the bishops to whom the task of overseeing the church and its doctrine naturally fell. As we know, they were increasingly aware of their active political role from at least 829 onwards, and episcopal power continued to be established locally and defined in a wideranging ecclesio-political discourse throughout the course of the ninth century. ${ }^{1}$

Yet the question of how and when bishops acted as both censors and literary patrons of new books within the Carolingian Empire has hardly been studied, even though it would appear rather important, and a great number of book dedications were made to bishops. The sources yield many references to procedures apparently akin to later 'censorship', variously called examinatio, correctio or even censura. As will emerge in more detail in the course of this chapter, such 'censorship' cannot merely be understood as standardized control or even as a particularly repressive activity in the earlier and high Middle Ages. ${ }^{2}$ As I would like to argue in the following essay, the supervision of doctrine was increasingly perceived as a productive and useful aspect of the office of the bishop in the first half of the ninth century because it was closely intertwined with patronage of learning and religious writing. As I shall attempt to demonstrate, portraying bishops as patrons allowed the formation of an ideal image of the bishop as 'guardian of doctrine'. And by according the episcopacy

\footnotetext{
${ }^{1}$ For the role and self-image of bishops in the Carolingian period, see the exhaustive treatment by Steffen Patzold, Episcopus: Wissen über Bischöfe im Frankenreich des späten 8. bis frühen 10. Jahrhunderts, Mittelalter-Forschungen, 25 (Ostfildern: Thorbecke, 2008) with references to the older literature.

${ }^{2}$ For literature on censorship in the Middle Ages, see the recent overview in Thomas Werner, Den Irrtum liquidieren. Bücherverbrennungen im Mittelalter (Göttingen: Vandenhoeck \& Ruprecht, 2007), esp. pp. 17-19. For Late Antiquity, see esp. Wolfgang Speyer, Büchervernichtung und Zensur des Geistes bei Heiden, Juden und Christen, Bibliothek des Buchwesens, 7 (Stuttgart: Hiersemann, 1981); for the Middle Ages, see Peter Godman, The Silent Masters. Latin Literature and its Censors in the High Middle Ages (Princeton: Princeton University Press, 2000); Luca Bianchi, Censure et liberté intellectuelle à l'université de Paris (XII-XIV Siècles), (Paris: Les Belles Lettres, 1999); Hanna Vollrath, 'Bernhard und Abaelard. Ein Beispiel für die Entstehung von Zensur in einer Umbruchsituation', in Kanon und Zensur, ed. by Aleida and Jan Assmann, Beiträge zur Archäologie der literarischen Kommunikation, 2 (Munich: Fink, 1987), pp. 309-316; G. B. Flahiff, 'Ecclesiastical Censorship of Books in the Twelfth century', Mediaeval Studies, 4 (1942), 1-22; Donald H. Wiest, The Precensorship of Books. Canons 1384-1386, 1392-1394, 2318 \& 2. A History and a Commentary, Canon Law Studies, 329 (Washington D.C.: Catholic University of America Press, 1953); Joseph Hilgers, Die Bücherverbote in Papstbriefen. Kanonistisch-bibliographische Studie (Freiburg: Herder, 1907).
} 
much religious and intellectual prestige, this image-formation may in turn have helped the development of ideas of censorship and control of doctrinal writing.

A source example that encapsulates some of the ideas inherent in episcopal censorship in the earlier Middle Ages comes from the pen of the famous Northumbrian teacher Alcuin of York $(\dagger 804)$, one of the well-known scholars connected to the court of Charlemagne around 800. In the context of the controversy over Adoptionism in the 790s, Alcuin submitted a treatise against the Adoptionist archbishop Elipand of Toledo to a group of bishops and abbots in Southern France. In his accompanying letter, he stated: 'judicio vestrae auctoritatis atque sanctitatis tantummodo contentus, nec in publicas aures easdem meae devotionis litterulae procedere velim, nisi prius vestrae auctoritatis censura examinentur, et fraternae congregationis lectione confirmentur'. ('I am content with the judgment of your authority and sanctity, and do not want my devoted writing to go out unto public ears unless it has been examined in censorship by your authority, and confirmed in a reading of the fraternal congregation'). ${ }^{3}$ In another letter, dedicating his prosimetric Vita Sancti Willibrordi to Archbishop Beornrad of Sens $(\uparrow 797)$, Alcuin similarly asked for a censoring judgment: 'Sed et omnia quae [...] dictavi, tuae sanctitatis spectant judicium, utrum digna memoriae, an pumice radenda feroci; nec nisi tuo roborata examine procedant in puplicum'. ('But everything I have dictated [...] awaits the judgment of Your Holiness, whether it be worthy of remembrance, or to be erased with savage pumice. Only corroborated by your examination should it go out to the public'). ${ }^{4}$

In a few well-put lines, Alcuin manages to evoke a striking image of precensorship (censura praevia), the main form of ecclesiastical censorship of books in the Middle Ages. ${ }^{5}$ Used from late antiquity onwards, this form of censorship prescribed a public reading and/or examination of a doctrinal text before circulation, either by a bishop and his advisors, by a council, or by the pope. As Alcuin put it, texts might or might not be 'worthy' to enter a public sphere of the church in written or aural (publicas aures) form. To safeguard this hypothesized space of ecclesiastical communication, bishops and abbots should not be squeamish in their wielding of the 'savage pumice', a somewhat fanciful image for the various devices used for erasing writing from parchment. According to the ideal image that Alcuin painted, their duty to preserve the purity of doctrine made bishops natural gatekeepers of a sphere of ecclesiastical writing, and thus censors.

Whether this amounts to actual 'censorship' has not been discussed in much detail and the general view of early medieval censorship we can glean from extant research appears extraordinarily ambivalent. ${ }^{6}$ A glance at Alcuin's two references illustrates this attitude. On one hand, he implies a plausible necessity for careful political handling of doctrine in the controversy over Adoptionism in

\footnotetext{
3 Alcuin, Contra epistolam sibi ab Elipando directam libri quatuor, ed. by Jean-Paul Migne, Patrologia Latina 101 (Paris: J.P. Migne, 1851), cols. 231-71 (col. 232).

4 Alcuin, Epistolae, ed. by Ernst Dümmler, Monumenta Germaniae Historica, Epistolae 4, Epistolae karolini aevi II (Berlin: Weidmann, 1895), pp. 18-481 (p. 175, No. 120).

${ }^{5}$ See the literature above in $n .2$.

${ }^{6}$ For thoughts on early medieval censorship, we mostly have to rely on brief reflections in works treating later periods, e.g. Godman, Silent Masters, pp. 4-31; Werner, Den Irrtum liquidieren, pp. 127-30; Speyer, Büchervernichtung und Zensur, pp. 121-76; Hilgers, Die Bücherverbote, pp. 315; Wiest, The Precensorship of Books, pp. 10-14 (all in n. 2).
} 
the 790s. ${ }^{7}$ But his insistence that even a Saint's life needed Archbishop Beornrad's censura seems suspiciously overeager. If we look at other letters of dedication by Alcuin, it quickly emerges that the Northumbrian scholar did not mean to imply that systematic censorship of all writings was generally necessary.

A second dedication in the same genre, of Alcuin's Vita Sancti Vedasti to Abbot Rado of Saint-Vaast, lacks the pointed reference to censorship. In a strikingly different plea for examination, Alcuin merely asked his friend Rado to praise or criticize the work, since he had encouraged its conception. Alcuin was sending the Vita as a gift: 'vestrae haec munuscula direxi pietati, obsecrans, ut tam humili ea fraternitatis intuitu respicere digneris, quam nos pia devotionis caritate illa vobis dirigere studuimus'. ('I am sending this as a little gift to Your Piety, out of faithful brotherly love, asking for it to be regarded with a humble observance of brotherhood fitting the spirit of pious and devout love in which it has been sent'). ${ }^{8}$ Not only is the formalized process of examination watered down to a request for friendly praise or criticism, but the telltale designation of the text as a gift (munusculum) puts the whole exchange firmly in a different context, that of literary exchange within and between scholarly and ecclesiastical networks. Once it becomes clear that Alcuin did not consider it strictly necessary to ask for pre-censorship at all times and for all genres, his formal plea for censorship to Archbishop Beornrad of Sens appears in a different light. Alcuin was apparently trying to express his respect for Beornrad's ecclesiastical role and rank -highlighting for example his own modesty and humility by speaking of Beornrad's 'command' to write, and referring to his own resulting 'obedience' and 'charity' in dedicating the work. ${ }^{9}$ Though this was a multi-layered relationship, Alcuin's dedication and appeal for censorship to Beornrad appears to reinforce a patronage relationship ${ }^{10}--$ as do similar appeals by other authors. ${ }^{11}$

\footnotetext{
${ }^{7}$ For the context, see John C. Cavadini, The Last Christology of the West: Adoptionism in Spain and Gaul, 785-820 (Philadelphia: University of Pennsylvania Press, 1993).

${ }^{8}$ See the context passages, Alcuin, Epistola 74, MGH Epistolae 4, pp. 116-17 (as in n. 4): 'nihil tuae reverentiae iussis denegare ratum putavi. Idcirco ad te maxime pertinet harum laus vel vituperatio litterarum [...] Et ego quamvis scientia inops, tamen fraterno fidelis amore, vestrae haec munuscula direxi pietati' etc.

${ }^{9}$ See Alcuin's opening of the letter to Beornrad, Alcuin, Epistola 120, MGH Epistolae 4, p. 175 (as in note 4): 'Delatis ad nos vestrae excellentiae litteris [...] magno me gaudio affectum esse fateor. Sed tamen longe imparem me petitioni vestrae consideravi, utpote nullo praerogativae munere eloquentiae suffultus, ad implendum quod iussisti; ac nisi me caritas urgeret, quae nulla negare solet, non auderem ultra meae paupertatis vires negotium attingere.'

10 To avoid misunderstandings, it must be stated clearly that speaking about a 'patronage' relationship in this instance does not imply denouncing Alcuin's dedications of his books as openly or solely instrumental. Given the opacity of the source genre, this could hardly be decided either way, even if it seems highly unlikely that Alcuin saw book-gifts primarily as means to a social end. Here, the term 'patronage' is used to describe a hierarchical relationship, in which Beornrad was nevertheless obliged to recognize Alcuin's abilities as an expert on doctrine and as an author. See e.g. the classic treatment in Shmuel N. Eisenstadt and Luis Roniger, Patrons, Clients and Friends: Interpersonal Relations and the Structure of Trust in Society (Cambridge: Cambridge University Press, 1984).

${ }^{11}$ Literature is scarce for the earlier Middle Ages, but see Joachim Bumke, Courtly Culture: Literature and Society in the High Middle Ages, trans. by Thomas Dunlap (Berkeley: University of California Press, 1991), first published in German, 1986. For analysis of prologues and letters of dedication detailing mechanisms of book dedication: Gertrud Simon, 'Untersuchungen zur Topik der Widmungsbriefe mittelalterlicher Geschichtsschreiber bis zum Ende des 12. Jahrhunderts', Archiv für Diplomatik, 4 (1958), 52-119 [part 1] and Archiv für Diplomatik, 5/6 (1959-60), 73-153 [part 2]; Tore Janson, Latin Prose Prefaces: Studies in Literary Conventions, Studia Latina Stockholmensia, 13 (Stockholm: Almqvist \& Wiksell, 1964).
} 
This connection of censorship with patronage is hardly surprising. It would seem that bishops make almost natural addressees for book dedications by young monks or clerics, and their office would also imply a role as censor. But these connections have not been explored in any detail in the extant research and neither has the nature of censorship in the earlier Middle Ages nor has the idea that bishops acted as censors.

One reason for this is that modern observers have often doubted that 'censorship' existed in the earlier Middle Ages. Given the unsystematic nature of his references, for example, Alcuin does not seem to be as concerned with the control of doctrinal writing as his resounding words on 'savage erasing' to Beornrad imply. The unsystematic, apparently merely situational distribution of references to examinatio or censura implies that there was no real ecclesiastical censorship of books in this period. The literature unanimously states that, in theory, concepts of pre- and post-publication censorship were known from late antiquity onwards (censura praevia, censura repressiva), as was the notion of a list of 'forbidden' books such as the Decretum Gelasianum de libris recipiendis et non recipiendis. But records of actual censorship are limited to a few, wellknown cases connected to larger, politicized controversies, and we have only sporadic mention of censorship outside of those examples, which do not seem to have prompted any episcopal action. Significantly, we have only a single instance of a letter documenting papal pre-censorship for the whole Carolingian period. ${ }^{12}$ Extant research concludes that we have to wait for the twelfth century and its exponential increase in the number of schools and scholarly mobility for censorship to become an institutionalized and formalized practice.

But then, what do we do with the many instances of books being dedicated to bishops, abbots and kings with accompanying pleas for examination, censorship and correction? Most literature on this question has discounted them, stating that the sentences were taken to be mere topoi, empty words. ${ }^{13}$ But this situation leaves much to be desired and indeed seems somewhat ironic. Even today, the twelfth century is habitually presented as the period of increasing academic and intellectual freedom par excellence, while the earlier Middle Ages and the Carolingian church in particular often enough continue to be portrayed as restrictive, pointedly orthodox and intellectually narrow. This description of Carolingian culture as highly 'repressive' directly conflicts with the assumption that it knew no institutionalized control of doctrinal writing. ${ }^{14}$ To uphold both notions, Peter Godman had to take recourse in the vague formulation that even if formal procedures may have been lacking, the early medieval centuries would have witnessed a 'mentality' of censorship. ${ }^{15}$ But if we ask for documentation or further illustration of such a repressive mentality, it seems that we can only point to the same topoi of correction that have been routinely discarded as meaningless in the search for formalized mechanisms of control.

\footnotetext{
${ }^{12}$ See Robert Somerville, 'Pope Nicholas I. and John Scottus Eriugena: JE 2833', Zeitschrift der Savigny-Stiftung für Rechtsgeschichte -- Kanonistische Abteilung, 114 (1997), 67-85.

${ }^{13}$ See e.g. Speyer, Büchervernichtung und Zensur, p. 176. Most similar judgments are influenced by Ernst Robert Curtius, European Literature and the Latin Middle Ages, trans. by Willard R. Trask, Bollingen Series, 36 (Princeton: Princeton University Press, 1991), e.g. pp. 82-105, first published in German, 1948.

${ }^{14}$ Compare, for example, Vollrath, 'Bernhard und Abaelard', p. 315 (as in n. 2).

${ }^{15}$ Godman, Silent Masters, p. 26 (as in n. 2).
} 
This way of thinking about censorship in the earlier Middle Ages seems contradictory and unsatisfying. It remains caught up in a painfully ambivalent methodical stance on the hermeneutic status of topoi, and overlooks the possibility that verbal formulae may indeed have something to do with formalization of social practices and could be read, for example, as ritualized communication. In the following, I would like to propose a systematic study of references to censorship and related concepts. Engaging in this study will enable us to deal with three interconnected questions on the history of episcopal control of doctrine which have so far been left unanswered. First, if the topical references to censorship in early medieval writing are not really censorship -- then what are they? What do they do, and what ideals of bishops and scholars do they present? Second, in what sense can we talk about 'censorship' at all? Can we even surmise that early medieval censoring practices could work like modern ones -- in a period without modern notions of textuality, and indeed without marked concepts of 'theory', 'sentences', or 'theology' like the ones developed in the twelfth century? ${ }^{16}$ And if these considerations can be addressed, third, what does this tell us about the image of the episcopal office, and about the interaction between bishops and scholars? Might their exchanges of idealized images of their respective roles even have influenced the concepts of the episcopal teaching office, and the structure of an ecclesiastical sphere of communication?

The present chapter attempts to address all three questions. It explores first the social, then the epistemological, and finally the political angles of ninthcentury book dedications to bishops. Some important aspects such as the role of Carolingian kings and of popes can only be hinted at, and to keep the argument simple, examples shall only be drawn from a very limited number of texts. ${ }^{17}$ While the various aspects relating to the complex field cannot be discussed exhaustively, some tentative conclusions do emerge. It appears that episcopal censorship was made popular in the first half of the ninth century because scholars' desire to gain episcopal support prompted them to pointedly address bishops as censors. ${ }^{18}$

2. Idealizing the bishop: Social interaction and patronage patterns in book dedication

To shed some light on the social implications of book dedication, many cases of ninth-century scholars dedicating books to bishops could be cited besides Alcuin's evocative pleas for pre-censorship. But an especially illuminating example comes from one of his students, the scholar-monk Rabanus Maurus of Fulda $(*$ c. $783--\uparrow 856)$. In the year 819 , he dedicated a substantial

\footnotetext{
${ }^{16}$ See for example Gillian R. Evans, Old Arts and New Theology: the Beginnings of Theology as an Academic Discipline (Oxford: Clarendon Press, 1980); Eadem, 'Sententia', in Latin Culture in the Eleventh Century. Proceedings of the Third International Conference on Medieval Latin Studies, Cambridge, Sept. 9-12, 1988, ed. by Michael W. Herren, C. J. McDonough and Ross G. Arthur, Publications of the Journal of Medieval Latin, 5, 2 vols (Turnhout: Brepols, 2002), I, pp. 315-23.

${ }^{17}$ Besides the handful of texts used in the following pages, conclusions presented here are based on a broader study of the prologues, letter-treatises and letters of dedication from the period 790870 which are contained in the Monumenta Germaniae Historica Epistolae volumes 4, 5 and 6, ed. by Ernst Dümmler and others (Berlin: Weidmann, 1895, 1899 and 1925).

${ }^{18}$ For a more detailed treatment and full documentation, see my Kulturen des Lehrens im Frühund Hochmittelalter. Autorität, Wissenskonzepte und Netzwerke von Gelehrten, Norm und Struktur, 39, (Cologne: Böhlau, 2011), pp. 515-688.
} 
work to the bishop responsible for his monastery of Fulda, Archbishop Haistulf of Mayence $(\dagger 825)$. This was the De disciplina clericali, a handbook for the clergy and only Rabanus's second work. In his mid-thirties, Rabanus was a priest and Fulda's esteemed teacher, but he still had three years to go before he would be elected abbot of Fulda in 822 and decades more before eventually succeeding Haistulf as archbishop of Mayence in $847 .{ }^{19}$ As is typical for a letter from a younger scholar to a markedly higher-ranking ecclesiastic, Rabanus' carefully phrased dedication to Haistulf thus pays much attention to social and rhetorical conventions.

This becomes visible from the first lines of the letter, as Rabanus idealized Archbishop Haistulf's episcopal status considerably. In the first paragraph, Rabanus called Haistulf 'holy father', and then insisted on the Archbishop being 'honorable and lovable to all' because of his 'piety, faith and sound doctrine' ${ }^{20}$ Haistulf was thus described as practicing the pastoral ideals of spiritual fatherhood and amiability on one hand, and correct faith and doctrine on the other -- two halves of an ecclesiastical ideal that was deeply embedded in the Carolingian ecclesiastical reform agenda shaped by authors like Alcuin. ${ }^{21}$

In lauding Haistulf as an ideal bishop, Rabanus Maurus also portrayed himself as an ideal subordinate and knowledgeable scholar. He started by declaring that the book he was dedicating to the bishop was meant as a gift. ${ }^{22}$ Indeed, it was a counter-gift: since Haistulf had already shown much benevolence to him, Rabanus dared to offer his book, even if the gift was small (munusculum) and hardly worthy of the recipient. He was still confident that it would be accepted, since a spirit who was rich in goodness as Haistulf's apparently was or should be, would certainly respect the devotion of the giver more than the value

\footnotetext{
${ }^{19}$ For Rabanus's career and writing, see the overview in Hrabanus Maurus: Lehrer, Abt und Bischof, ed.by Raymund Kottje and Harald Zimmermann, Akademie der Wissenschaften und der Literatur: Abhandlungen der Geistes- und Sozialwissenschaftlichen Klasse, 4 (Mainz: Akademie der Wissenschaften und der Literatur, 1982); the appraisal in Mayke De Jong, 'Old Law and New-Found Power: Hrabanus Maurus and the Old Testament', in Centres of Learning: Learning and Location in Pre-Modern Europe and the near East, ed. by Jan W. Drijvers and Alasdair A. MacDonald, Studies in Intellectual History, 61 (Leiden: Brill, 1995), pp. 162-76; also see her 'The empire as ecclesia: Hrabanus Maurus and biblical historia for rulers', in The Uses of the Past in the Early Middle Ages, ed. by Yitzhak Hen and Matthew Innes (Cambridge: Cambridge University Press, 2000), pp. 191-226.

${ }^{20}$ See the relevant passage, Rabanus, Epistola 3, MGH Epistolae 5, p. 385 (as in n. 17): 'Domino reverentissimo ac religiosissimo Haistulfo archiepiscopo Hrabanus minimus servorum Dei servus aeternam in Christo optat salutem. Cum te, sancte pater, pro merito summę pietatis plurimi venerentur et omnibus fidelibus causa magnae fidei et sanæ doctrinæ honorabilis atque amabilis existas [...]' [continued in n. 23 below].

${ }^{21}$ See for example Marta Cristiani, 'Le vocabulaire de l'enseignement dans la correspondance d'Alcuin', in Vocabulaire des écoles et des méthodes d'enseignement au moyen âge. Actes du colloque, Rome, 21-22 Oct. 1989, ed. by Olga Weijers, Civicima: Etudes sur le vocabulaire intellectuel du moyen âge, 5 (Turnhout: Brepols, 1992), pp. 13-32.

${ }^{22}$ For concepts of gift-giving and gift exchange appearing in this dedication and related texts, see my 'Ammirabile commertium. Die Widmungen des Hrabanus Maurus und andere symbolische Geschenke als Gaben im Angesicht Gottes', in Geschenke erhalten die Freundschaft. Gabentausch und Netzwerkpflege im europäischen Mittelalter. Akten des Internationalen Kolloquiums Münster, 19-20 November 2009, ed. by Michal Grünbart, Byzantinistische Studien und Texte, 1 (Münster: Lit, 2011), pp. 209-49. See also Florin Curta, 'Merovingian and Carolingian Gift Giving', Speculum, 81 (2006), 671-99 and the recent contributions in The Languages of the Gift in the Early Middle Ages, ed. by Wendy Davies and Paul Fouracre (Cambridge: Cambridge University Press, 2010).
} 
of the gift. $^{23}$ The book's material value, Rabanus implied, might be inconsiderable, but his devotion in giving it was all the more real.

These lines put the dedication firmly in a context of scholarly exchange and literary patronage. The book is turned into an erudite gift, a token, which had separate social and symbolic worth in addition to its literary or material value. Haistulf's ritualized response to Rabanus's multi-layered gift would have been to show continued loving benevolence to his subject. This would, in turn, engender more respect and gifts from Rabanus, and so on. In this case, we know that a mutual exchange of real and symbolic gifts continued, with both the bishop and the scholar-abbot engaged in a felicitous give-and-take of symbolic and social capital. $^{24}$

But Rabanus did more than simply give his book away. He formally submitted it to censorship by Archbishop Haistulf:

Et hac fiducia ausus sum partem laboris mei $[\ldots]$ tibi, quem benignissimum et æquissimum esse scio, vice muneris dirigere, ut a te qualiscumque sit, reciperetur ac tuo sacro iudicio probaretur atque ad purum examinatur. [...] Proinde obsecro te, sancte pater, ut oblatum tibi opus suscipias ac pie relegens diligenter illud examines, et ita quæ in eo rationabiliter inveneris dictata, ei hoc tribuas, a quo est omnis ratio creata. $\mathrm{Si}$ qua vero inconsiderate repperieris prolata, tuo studio cito reddas illa emendata. Et sic credo legentibus erunt utilia. ("And because of this trust I have dared to send you, whom I know as very benevolent and just, a part of my work as a gift, so that it should be received by you, however it appears, to be tried by your sacred judgment, and to be examined for purity [...] And therefore I beseech you, holy father, to receive the offered work and to examine it diligently, in a pious reading. And this way, you will be able to attribute anything that you find reasonably said to Him who created reason. But if you should find any inconsiderate things, they can be quickly emended thanks to your zeal. And in this way they will be useful to the reader, I think.') ${ }^{25}$

Like his teacher Alcuin, Rabanus envisioned a detailed examination and correction of his book in a full-blown procedure of censura praevia. Going beyond Alcuin, Rabanus put this double enterprise of dedication and examination into a specific context. Alluding to the fact that Haistulf had been the bishop who ordained him, he added, 'Tuo enim magisterio semper me libens subdam, a quo recordor me accepisse dignitatem aecclesiasticam'. ('For I always submit voluntarily to your teaching office, remembering that from it I accepted my ecclesiastical dignity [i.e. the priesthood, S.S.]'). ${ }^{26}$ Personalizing the bond between himself as an author and his ecclesiastical superior, Rabanus established a connection between Haistulf's power to consecrate and his authority over the resulting doctrine of the subordinate. Rabanus was reminding the archbishop that he was his 'spiritual father' in a very specific and individual sense.

\footnotetext{
${ }^{23}$ Rabanus, Epistola 3, MGH Epistolae 5, p. 385: [continued from n. 20 above] '[...] congruum esse iudicavi, ut ego, in quem plurimum tuorum beneficiorum contulisti, aliquod munusculum, licet non condignum, tamen ut credo non ingratum, tuæ venerationi deferrem, nihil verens de pretio, quia animus in bonitate dives magis estimat devotionem offerentis quam donum'.

${ }^{24}$ For the following exchanges, see Rabanus, Epistolae 5-6, MGH Epistolae 5, pp. 388-91.

${ }^{25}$ Rabanus, Epistola 3, MGH Epistolae 5, pp. 385-86.

${ }^{26}$ Rabanus, Epistola 5, MGH Epistolae 5, p. 386 [continued from passage quoted at n. 22].
} 
The use of the term magisterium for an ecclesiastical teaching office, which typically brings to mind much later debates, is all the more interesting in this instance as it is not often used for bishops in ninth-century sources. ${ }^{27}$ Recent research has emphasized that the conceptual framework of lay and ecclesiastical political power was reworked fundamentally in Carolingian Francia in the first half of the ninth century. ${ }^{28}$ But as Steffen Patzold has made quite clear, ministerium remained the keyword for the episcopal office, magisterium as a term appears only rarely. ${ }^{29}$

The effect of Rabanus's elegant wrapping of his scholarly gift-exchange into an idealized concept of episcopal and priestly office is clear. To call upon a magisterium, a doctrinal/scholarly part of Haistulf's official ministerium, put subtle but insistent pressure on the archbishop to pay attention to this author and his work. On a personal level, Haistulf may have been pleased by Rabanus's gift. But in his official capacity, he was obliged to acknowledge it because of the plea for episcopal examination and correctio, another political keyword in the ninth century. ${ }^{30}$ Haistulf had to take Rabanus seriously, read his book carefully, and put to it to good ecclesiastical use, because his episcopal office demanded it. Possibly quite unintentionally, Rabanus Maurus, in transforming his gift into a highly official duty, had reinforced the idea that censorship was an important part of the episcopal office.

\section{Idealizing knowledge: Epistemological aspects of book examinations}

If we go a step further and take the exact form and concept of apparent 'censorship' into consideration, contemporary ideas about knowledge come to the foreground. If we read Rabanus's De institutione clericali closely, the Fulda scholar not only asked Archbishop Haistulf to correct things that might be wrong, he asked him to select those things which were said reasonably (rationabiliter) and ascribe them to the creator of reason, God himself, while others should be 'emended'. 31

This is clearly a topos, and a very popular one in the ninth century, which could be called the topos of selection (as opposed to topical references to correction). Rabanus himself used it many times, as had his teacher Alcuin before him, walking in the footsteps of the church fathers. Other Carolingian scholars

\footnotetext{
27 There is no very clear-cut idea of magisterium in the earlier and high Middle Ages, and the term only gained prominence with nineteenth and twentieth debates on the Magisterium of the Catholic Church. For the earliest developments, see Yves Congar, 'Bref historique des formes du "magistère" et de ses relations avec les docteurs', Revue des sciences philosophiques et théologiques, 60 (1976), 99-112 ; reprint in Idem, Droit ancien et structures ecclésiales, Variorum Collected Studies, 159 (London: Ashgate Variorum reprints, 1982), VII. See also my Kulturen des Lehrens (as in n. 18).

${ }^{28}$ See e.g. Patzold, Episcopus; Mayke De Jong, The Penitential State. Authority and Atonement in the Age of Louis the Pious, 814-840 (Cambridge: Cambridge University Press, 2009); Staat im frühen Mittelalter, ed. by Stuart Airlie, Walter Pohl and Helmut Reimitz, Forschungen zur Geschichte des Mittelalters, 11/ Österreichische Akademie der Wissenschaften Philosophischhistorische Klasse, Denkschriften, 334 (Vienna: Österreichische Akademie der Wissenschaften, 2006).

${ }^{29}$ See Patzold, Episcopus, passim.

${ }^{30}$ See for example Philippe Depreux, 'Ambitions et limites des réformes culturelles à l'époque carolingienne', Revue historique, 307 (2002), 721-753 (pp. 732-7).

${ }^{31}$ See above at n. 22.
} 
down to John Scottus Eriugena in the third quarter of the ninth century would continue to employ it in their dedications. ${ }^{32}$ The idea behind it is quite intriguing: As Rabanus's words show, he distinguished two types of knowledge, God-given reasonable findings and his own human 'inconsiderate things'. It thus appears that he envisioned the knowledge relating to doctrine (later 'theology') as a broad dichotomy of divine truth and human error. ${ }^{33}$ In themselves, humans could not do good or recognize truth -- they needed divine grace. To clarify by contrast, it could be added that from the twelfth century onwards, this dichotomy would be replaced with a more nuanced model, in which various modes of human knowing were acknowledged, and considered to lead gradually to divine wisdom and absolute certainty. Besides fides, absolute 'faith', the twelfth century for example also postulated human opinions, opiniones, and human learning as scientia based intellectus. $^{34}$

In the ninth century, we see a much harsher division of knowledge into divine truth and human error. The thin line between the two was established by divine grace, which filled the exegete and teacher of doctrine with inspiration through the Holy Spirit. ${ }^{35}$ If it was absent, a human author would eventually err. But if it elevated him beyond the human plane, he could recognize and write about truth -- which he nevertheless owed to God. Rabanus would actually set this out as a general rule in his very handbook De disciplina clericali. Even if human authors expressed truth and wisdom, this still should be ascribed to God. These things were only understood by humans insofar as higher powers actively allowed them to investigate. ${ }^{36}$

While twelfth-century authors could handle and rearrange their merely human theories with considerable insouciance, ninth-century exegetes like Rabanus were somewhat limited by these assumptions. Carolingian doctrinal writers apparently assumed that, buoyed by the Holy Spirit, they were handling divine truth itself. And that was a dangerous business, calling for humility,

\footnotetext{
${ }^{32}$ For repeated use of this topos in Rabanus's letters, see Rabanus, Epistola 3, MGH Epistolae 5, p. 386 (as in n. 17), ibid., 19, p. 425; 27, p. 442; 34, p. 468; 35, p. 470; 42, p. 481. For Alcuin, see e.g. Alcuin, Epistola 80, MGH Epistolae 4, p. 123 (as in n. 4): 'si quid in eis perperam dixerim, tu fraterno stilo corrigere studeas; si quid vero bene, non mihi, sed largitori gratias age, qui et te proficere et me tibi sufficere ex donis suis faciat'. For John Scottus Eriugena, see Iohannis Scotti seu Erivgenae Periphyseon. Liber Quintus, ed. by Edouard A. Jeauneau, Corpus Christianorum, Continuatio Mediaevalis (CCCM), 165 (Turnhout: Brepols, 2003), p. 861.

${ }^{33}$ In this, Rabanus would have been in accordance with other ninth-century and earlier authors, going back in a clear line of tradition to Paul, who had underlined the role of grace in his non ego autem, sed gratia Dei mecum (I Corinthians 15. 10). See e.g. Christel Meier, 'Autorschaft im 12. Jahrhundert: Persönliche Identität und Rollenkonstrukt', in Unverwechselbarkeit. Persönliche Identität und Identifikation in der vormodernen Gesellschaft, ed. by Peter von Moos, Norm und Struktur, 23 (Cologne: Böhlau, 2004), pp. 207-66 (p. 209).

${ }^{34}$ For such concepts in the twelfth century, see in detail Frank Bezner, Vela Veritatis: Hermeneutik, Wissen und Sprache in der 'Intellectual History' des 12. Jahrhunderts, Studien und Texte zur Geistesgeschichte des Mittelalters, 85 (Leiden: Brill, 2005).

${ }^{35}$ Literature on epistemology in the earlier Middle Ages is scarce, but see Gillian R. Evans, Getting it Wrong: The Medieval Epistemology of Error, Studien und Texte zur Geistesgeschichte des Mittelalters, 63 (Leiden: Brill, 1998), pp. 68-9.

${ }^{36}$ Rabanus Maurus, De institutione clericorum: Über die Unterweisung der Geistlichen, ed. and trans. by Detlev Zimpel, Fontes Christiani, 61, 2 vols (Turnhout: Brepols, 2006), II, 3, c. 2, p. 462: 'Nec enim illa, quae in libris prudentium huius saeculi vera et sapientia reperiuntur, alii quam veritati et sapientiae tribuendae sunt, quia non ab illis haec primum statuta sunt, in quorum dictis haec leguntur, sed ab aeterno manentia magis investigata sunt, quantum ipsa doctrix et inluminatrix omnium veritas et sapientia eis investigare posse concessit'.
} 
awareness of one's own human fallibility, and consequently for caution in circulating a new work.

According to his own theory, Rabanus Maurus could hope and pray that God would inspire him with the truth. But he could never be arrogant enough to be certain of it. Aware of his own human frailty, he could never fully claim to know or to write true or wise things, especially when he went beyond known authorities such as the church fathers. ${ }^{37}$ Since Rabanus was subscribing to the notion of a broad dichotomy of divinely inspired truth and human error -- and actually reinforcing such a concept in the process -- he had no immediate way to determine the status of his own writing.

The solution to this dilemma leads to further insights into the function of topoi of correction in dedication letters, and of the role of bishops in the emerging scholarly endeavour of clarifying doctrine. To gain clarity about the status of his writings, Rabanus needed to have external confirmation of their quality, and that was exactly what Archbishop Haistulf was expected to give him. When Rabanus asked him for censura praevia and selection of true or erroneous passages, we can surmise that he was not only asking for a checkup on his doctrine, for censorship in the sense of control. He was also, and mainly, asking for approbation.

Given ninth-century ideas about sacred truth and human access to it through humility and adherence to authority, it could in fact only be Haistulf's acceptance of the work -- in his official capacity as bishop, representing the church -- that completed and confirmed the text and gave it status as an orthodox and inspired book. Receiving such an endorsement, which, to early medieval authors, was implicit in silent acceptance of a work, ${ }^{38}$ gave Rabanus the status of an orthodox and divinely inspired author. In his case, we know that news about his inspiration spread quickly. Only a few years later, bishop Frechulf of Lisieux would implore him to write down what inspiration had told him. Eventually, the Emperor Lothar I himself would call Rabanus a light of doctrine, and even put him on a par with the church fathers Jerome, Augustine, Gregory and Ambrose. ${ }^{39}$

But this elevated status and a task as important as the explanation of doctrine, carried its own dangers. If a scholar handled divine truth and Christian doctrine, he was in fact exercising a kind of magisterium himself or herself, as the case might be. ${ }^{40}$ And since Carolingian thought did not possess a concept of 'learning' approximating the later sense of scientia, expertise on doctrinal matters could not be seen as a province of experts. In theory, episcopal authority over doctrine was a cornerstone of ecclesiastical order -- even if lowly monks or clerics sometimes surpassed bishops as biblical scholars. But in practice, ecclesiastical office-holders and scholars without such offices had the same teaching function and taught the same divine truth. This latent competition

\footnotetext{
${ }^{37}$ For an appraisal of Rabanus' exegesis, which presented new arguments fairly frequently, see De Jong, 'Old Law and New-Found Power', passim (as in n. 19).

${ }^{38}$ See Simon, 'Untersuchungen', part 1, p. 61-62 (as in n. 11).

${ }^{39}$ See Rabanus, Epistola 7, MGH Epistolae 5, p. 392 (Frechulf), Epistola 49, p. 504 (Lothar I.) (as in n. 17).

${ }^{40}$ One of the most interesting aspects of early medieval concepts of a 'teaching office', which begs comparative study, is that the vocabulary of magisterium was also ascribed to women. See for example the Vita Leobae by Rudolf of Fulda, himself a disciple of Rabanus, "Vita Leobae abbatissae Biscofesheimensis auctore Rudolfo Fuldensi', ed. by Georg Waitz, Monumenta Germaniae Historica, Scriptores 15.1 (Hannover: Weidmann, 1887), pp. 118-31.
} 
between bishops and scholars had to be rather upsetting if it was openly discussed. Possible differences in learning had to be explained away, or somehow made invisible. As a study of the distribution of topoi of correction shows, Carolingian scholars did this in a quite systematic manner, and found various complementary solutions to address the underlying dilemma.

For example, scholars could allude to the concept of an episcopal magisterium by stating that they, in the name of humility, did not wish to teach a superior. ${ }^{41}$ Especially in prologues or widely circulating treatises, this could be boiled down to a formula declaring 'readiness to accept correction', as for example, 'Haec ergo iuxta id quod sensimus et a magistris traditum accepimus, stylo protulimus, non praeiudicantes his, qui melius sapiunt ac melius sermonibus proferre norunt'. ('All this we propose according to what we feel and what we have learned from our masters, but not to the prejudice of others, who may know better and will put this in better words'). ${ }^{42}$ Alternatively, scholars could assert that the bishop they addressed probably knew all that was written already. Being part of the apostolic hierarchy, a bishop was already 'conscious of divinity'. 3 Finally, scholars could always ask a bishop for pre-censorship as with Rabanus in the case of Haistulf, and thus ascribe a superior position in the magisterium to him. ${ }^{44}$ While often rather transparent, these strategies allowed scholars to frame their interaction with bishops in an idealized social order. This apparently allowed order to be upheld even though the scholars' presence threatened an older idealized concept of an apostolic hierarchy, in which bishops and abbots were always meant to take precedence over their subordinates. Younger scholars, who were dedicating their first works to higher-ranking patrons, usually seem very conscious of this hierarchy. Not least, they emphasized an episcopal magisterium to produce a binding obligation for the bishop as patron, as we have seen with Rabanus.

In the speculative debates and controversies that were developing in the first half of the ninth century, ${ }^{45}$ however, scholars had to take more than ecclesiastical rank into account. Given the epistemological dichotomy of divine truth and human error, they not only lacked a concept of scientia. There was also

\footnotetext{
${ }^{41}$ See e.g. an anonymous letter in which a former student successfully demolished a teacher's opinion, and then added: 'Hoc autem dico, Deus scit, non docere affectans, qui nichil sum, sed discere cupiens in quod libentissime promtus sum, neque pertinaciter refellens, sed humiliter quaerens [...], Epistolae Variorum, ed. by Ernst Dümmler, Monumenta Germaniae Historica, Epistolae 6, (Berlin: Weidmann, 1925), No. 26, p. 184.

${ }_{42}$ Rabanus Maurus again, in a dedication of his Commentary on the Song of Songs, Rabanus, Epistola 33, MGH Epistolae 5, p. 467 (as in n. 17).

${ }^{43}$ For an especially illuminating example, see an anonymous letter in MGH Epistolae 5, Variorum Supplementum No. 11, p. 635 (as in n. 17): 'Unum certe scio idque animo persuasi meo: vos ad hoc interrogasse, ut doceretis; requisisse, ut veri callis tramitem ignaro previus ipse monstraretis. Quod enim remota subdolæ adolationis suspicione liceat dicere, non necesse habetis, ut aliquis vos doceat, quia mistica sancti Spiritus eruditio sacro pontificalis unguinis crismate coaptans vos de omnibus cælestis benedictionis plenitudine consecratum edocuit et quadam mirabili metamorphosi in virum alterum, immo in apostolicam ierarchiam transfusum, in Domini potentias, sapientiæ videlicet scientiæque thesauros, introduxit atque ipsius divinitatis conscium reddidit.'

${ }^{44}$ Thus for example John Scottus Eriugena (as in n. 32) or, to cite a random example, abbot Otfried of Weissenburg in his German translation of the Gospel harmony, vis-à-vis archbishop Liutbert of Mayence, MGH Epistolae 6, Epistolae Variorum, No. 19, p. 169 (as in n. 17).

${ }^{45}$ For an overview, see David Ganz, 'Theology and the organisation of thought', in The New Cambridge Medieval History: c. 700-900, ed. by Rosamond McKitterick, 7 vols (Cambridge: Cambridge University Press, 1995), II, 758-85.
} 
no very clear concept of 'opinion'. ${ }^{46}$ Everything that was not truth logically had to be error, not simply a mistake. Such error would even constitute heresy when defended.

But Carolingian scholars did want to advance opinions. Quite sensibly, they did not understand every word they wrote as sacred truth. They were clearly conscious of the social and epistemological implications of debating truth, and were thus careful to demonstrate that they did not mean to defend their words with heretical stubbornness, pertinacia. ${ }^{47}$ The typical way to mark a statement as an 'opinion' avant la lettre was, again, to ask the recipient of a book or a treatise to correct it. Scholars also added generalized statements declaring their willingness to be corrected. Such 'safety clauses', which toned down the validity of scholars' assertions to mere hypotheses, may in fact be seen as the direct forerunners of late medieval salva-fide clauses. ${ }^{48}$

If we consider these functions of the frequent topoi of correction, that is, as tools for negotiating the respective rank of the author and recipient of a text and the respective validity of the statements, a pattern emerges from their seemingly sporadic use and random distribution. In the twelfth century, censorship would be keyed to a medium or to physical boundaries, to ensure examination whenever something was written down, or left a circumscribed space like a monastery. Ninth-century pleas for correction were primarily keyed to the rank of the recipient and specific situations. As far as can be ascertained, authors of doctrinal writing always negotiated their respective authority vis-à-vis higher-ranking recipients of books, such as bishops, kings and abbots -- unless, the one great exception, they were on very familiar terms with them. Also, debates conducted by letter almost always prompted the use of typical formulae.

If patron-client relationships between bishops and scholars indeed had this strong influence on the rules of book dedication and ecclesiastical control, it seems hardly surprising that we know of very few actual rebuttals, and of even fewer formal approvals of submitted books. ${ }^{49}$ The written demonstrations debated here mainly demonstrate awareness of rules and norms. They permitted a bishop who was less learned than his scholarly client to save face. Equally, an opinion could be marked as a debatable, hypothetical argument by mentioning correction, and in both cases, this worked with or without replies and reactions. On a methodical level, the topoi and formulae of correction written in ink and parchment can indeed be analysed exactly like gestures. While based on a written discursive logic, they were also highly performative, and we could indeed understand them as gestures on parchment. Quite far from being empty words, they appear as ritualizations that helped to uphold the social and epistemological order of the early medieval church.

\footnotetext{
46 The ninth century also lacks the concept of 'sentence' as in twelfth-century sententiae. For these, see Evans, 'Sententia', passim (as in n. 16).

${ }^{47}$ See e.g. the text cited in $n .41$ above.

${ }^{48}$ On late medieval developments, see Sylvain Piron, 'Ecrire en Aveugle: Jean de Roquetaillade ou la Dissidence par l'Obéissance', in Autorität und Wahrheit: Kirchliche Vorstellungen, Normen und Verfahren (13. bis 15. Jahrhundert), ed. by Gian Luca Potestà, Schriften des Historischen Kollegs, 84 (Munich: Oldenbourg, 2012), pp. 91-111.

${ }^{49}$ For the extant approvals, see Simon, 'Untersuchungen', part 2, pp. 133-36 (as in n. 11).
} 
4. Ideals and practices: Bishops, scholars, and the dimensions of ecclesiastical control

To describe the overall structures that emerged from the practices discussed so far, it may be helpful to add what the chronology of topoi and 'safety clauses' in ninth-century doctrinal writing can tell us. The patterns of communication discussed here do seem to gain in clarity and uniformity with the spread of learning from the court of Charlemagne. Frequently, successive generations of scholars would have handed them on to their students. In the case of Rabanus, for example, specific similarities make clear that he learned mechanisms of handling book-dedications and censorship from his teacher Alcuin. But the ritualizations they and their contemporaries employed lose coherence in the second half of the ninth century, when the Carolingian Empire had broken up into smaller, localized communities of schools and scholars. Censorship simply stopped being a common concern, until the late eleventh century, when it surfaced again in rather different circumstances.

But another, more short-term pattern of development would make much more sense than a model of continuous growth, and still allow some insight into the growth of norms and ideals within the church. The ninth-century formulae and 'written gestures' of censorship frequently seem to have evolved around controversies especially the cause célèbre of ninth-century doctrinal debates, the heavily politicized conflict over divine predestination in the years 848 to $859 .{ }^{50}$ This conflict was initiated by the monk Gottschalk ( $\dagger$ c. 869 ), who provoked a controversy about the nature of divine predestination. While inciting much scholarly debate, he also created unrest by announcing to broader audiences of his itinerant preaching that some people were predestined to be damned, and that good works would not save them. In this debate, the rather flexible ideas and formulations about examination and correction, which had so far mostly been uttered voluntarily, seem to have crystallized momentarily into rather rigid norms.

For example, actual 'correction', when it came, took the form that Rabanus Maurus and other scholars had envisaged. While some apologetic writing of Gottschalk's was burned in toto, his condemnation primarily concerned his preaching, rather than a 'book' he had written. But when debate broke out over the legitimacy of this condemnation, other scholars were asked to write treatises, or wrote and published them on their own initiative. A heavy attack was then made on a treatise about predestination written by the Irish court scholar, John Scottus Eriugena ( $\dagger$ after 875), famous then as now for the sophistication of his unusual theology. Bishop Prudentius of Troyes $(\dagger 861)$ was asked to correct John's book, and found various errors. He flagged them, like the topos of selecting 'inspired' from 'erroneous' passages envisioned, and famously marked errors with a Greek 'theta' signifying death. ${ }^{51}$ This led to further mishap. Archbishop Hincmar of Rheims ( $†$ 882) had commissioned the Irishman's treatise, initially endorsing its contents by accepting its dedication. In a rather

\footnotetext{
${ }^{50}$ See the overviews in David Ganz, 'The Debate on Predestination', in Charles the Bald. Court and Kingdom, ed. by Margaret T. Gibson and Janet L. Nelson, $2^{\text {nd }}$ ed (Aldershot: Variorum, 1990), pp. 283-302; Celia Chazelle, The Crucified God in the Carolingian Era: Theology and the Art of Christ's Passion (Cambridge: Cambridge University Press, 2001), pp.165-208.

${ }^{51}$ See Prudentius of Troyes, De Praedestinatione contra Johannem Scotum [...] Liber, ed. by Jean-Paul Migne, Patrologia Latina 115, (Paris: J.P. Migne, 1859), cols. 1009-1366 (cols. 1011$12)$.
} 
awkward maneuver, he then had to extricate himself from his responsibility as the addressee of John's dedication and his failure to actively censor the work as seemingly required by his episcopal status, claiming publicly that he had never heard of it before. $^{52}$

To negotiate embarrassing situations like this one, or even just to enable the exchange of opinions among ecclesiastical leaders and scholars, pleas for correction also saw extensive use as 'safety clauses' and marks of polite rather than savage exchange. Rabanus, for example, managed to exchange opinions with his archiepiscopal colleague Hincmar of Rheims without compromising their respective authority. He humbly asked Hincmar to approve his writings, but asserted his own authority by approving Hincmar's work in the same breath. ${ }^{53}$ The monk Ratramnus of Corbie ( $\dagger$ c. 868 ), a scholar without higher office, took a clear stance against Archbishops Rabanus and Hincmar. But he submitted his treatise for correction to King Charles II $(\dagger 877)$, to ensure that, if necessary, he would be given a locus defensionis. ${ }^{54}$ Bishop Prudentius of Troyes, who had been asked to correct the treatise of John Scottus Eriguena by archbishop Guenilo of Sens $(\dagger 856)$, did end up correcting the Irish scholar's treatise. But cautiously pursuing a shared policy, Prudentius also asked archbishop Guenilo for a correction of his correction. ${ }^{55}$ While all this posturing and 'written gesturing' appears somewhat laborious, the topical references to correction and censorship emerge as highly functional. Even though an utter breakdown of communication should have been the consequence of the bitter doctrinal differences, the ecclesiastical writers involved managed to avoid it.

The debate on predestination yields one additional fascinating document. At least one bishop had bothered to check the writings of the accused monk Gottschalk for 'safety clauses'. This reader, Archbishop Amolo of Lyon ( $†$ 852), found that Gottschalk's writing lacked them. He thus accused him of a 'malum in moribus tuis', a 'fault' in his 'morals'. Having no good name for the practice of asking for examination or correction, Amolo had to describe it by giving an example. ${ }^{56}$ But this still allows us to conclude that at least for Amolo, submitting writing for correction had now become a norm. At this point, clauses and ideas that scholars had mainly introduced to further their own ends -- to please bishops and gain patronage, to enable them to communicate and to demonstrate their savoir-faire -- had now suddenly turned into constraints on their own behaviour. Having been cast in the role of censors for some decades, Carolingian bishops now acted on this ideal. To employ the image used by Alcuin, they now had the 'savage erasing pumice' in their hands, but it may have been the scholars who handed it to them.

If one looks for censorship practices which can be compared to modern or late medieval ones, Carolingian Francia simply lacked them. This was especially

\footnotetext{
52 See Hincmar of Reims, De praedestinatione, ed. by Jean-Paul Migne Patrologia Latina 125 (Paris: J.P. Migne 1959), cols. 49-473 (col. 51).

${ }^{53}$ Rabanus, Epistola 44, MGH Epistolae 5, p. 490, 498 (as in n. 17).

${ }^{54}$ Ratramnus, Epistolae Variorum No. 9, MGH Epistolae 6, p. 151 (as in n. 17).

${ }^{55}$ Prudentius, De praedestinatione, col. 1012 (as in n. 51).

${ }^{56}$ Amulo, Epistola 2, MGH Epistolae 5, p. 377 (as in n. 17): 'Alterum vero malum est in moribus tuis, quod in omnibus quę dicis et sentis, sicut scriptura tua declarat, nullum omnino hominum more bonorum pie et humiliter deprecaris, nullius te sensui et auctoritati summittis, nec dicis quod sepe solet et debet pietas dicere: 'Obsecro, bone vir aut bone frater, si in his quae dico aliquatenus erro, ferto infirmitatem meam, instruito ignorantiam meam, et probabis oboedientiam meam, quia paratus ero libenter suscipere quicquid veritas dignabitur declarare'.
} 
true for forms of standardized control of doctrinal writing at publication, later introduced by the mendicant orders. In contrast to this model, Carolingian bishops seem to have had little interest in systematically checking all their subordinates' literary productions. But power and authority are not necessarily always imposed from above. As Patzold's work on Carolingian bishops emphasizes, for example, power also depends on being ascribed from below by its subjects. ${ }^{57}$ This mechanism may have been at work in gradually establishing censorship as an active component of the episcopal office during the first half of the ninth century. We have a large number of sources in which Carolingian authors ascribe the authority to examine and correct doctrinal writing to bishops, frequently described in idealizing language which was actually meant to flatter and generate obligation. Seen over time, this activity seems to have amounted to - as it were -- norm-building from below. While the developments are largely unsystematic and driven by specific situations, shared expectations about concepts of knowledge, of censorship, and of the social status of scholars with respect to bishops seem to have developed. In the debate about predestination, these expectations crystallized into norms, at least momentarily.

If we ask what these norms meant for the ecclesiastical control of doctrinal writing, the documented patterns still do not amount to a control of all writing. Many books, especially those only circulated among the friends of the authors, would never have gone through a bishop's or abbot's hand. But the custom of always ceding authority to higher-ranking ecclesiastics still implies a measure of control within a sphere of communication dependent on their physical or imagined presence. While this does not totally coincide with modern or secular notions of a public sphere, it could be called an ecclesiastical public sphere. ${ }^{58}$ Ninth-century contemporaries would certainly have called it ecclesia.

As a whole, the Carolingian church may thus not have known an official approval such as later 'Nil obstat' remarks. But it developed a specific social and epistemological order relating to the control of doctrine. It was primarily the hierarchical socio-political order of the church, and of Carolingian society as a whole, that provided the patterns and structured the forms of communication. Within an ecclesiastical public sphere built around higher ecclesiastical officeholders (which would have included various kings), ritualized interactions like the practices of inserting 'safety clauses' in dedications grew up to prevent loss of face and open conflict.

If we are looking for the 'mentality' of censorship proposed by Godman, ${ }^{59}$ this is it. And to some modern scholars, the measures necessary to communicate about doctrine within the Carolingian church may well feel 'repressive'. Read as ritualized communication, however, the formulae used in prologues and letters of dedication do not seem very different from the good manners of a courtier. Any ninth- or tenth-century noble would have known that it was inadvisable to publicly lecture or contradict a king. To assert influence, a good courtier would

\footnotetext{
${ }^{57}$ See Patzold, Episcopus, pp. 37-41(as in n. 1).

${ }^{58}$ For discussion of medieval applications of the term 'public sphere', see Leidulf Melve, Inventing the Public Sphere: The Public Debate during the Investiture Contest (c. 1030-1122), Studies in Intellectual History, 154, 2 vols (Leiden: Brill, 2007).

${ }^{59}$ See Godman, Silent Masters, p. 26 (as in n. 2).
} 
allow the king to save face in public, and negotiate in private. While not written down anywhere, these were the 'rules of the game'. ${ }^{60}$

With their careful topoi, Carolingian scholars seem to have established a comparable suspension of established norms. In putting the social and epistemological order of the church into words in their writings, authors with or without ecclesiastical office inscribed a social space in which hierarchy was suspended. Their explicit upholding of ecclesiastical authority on a theoretical plane allowed them to mold it on parchment, and thus to move around it with astonishing freedom. Lowly monks contradicted bishops, colleagues exchanged opinions over immutable truth, and students even managed to correct their own former teachers -- all things that we would still find surprising in the twelfth century.

To the modern mind that finds all censorship odious, this ordering of social interaction may still not appear very civilized. But for a world that knew no middle ground of 'theory', and which had to see everything in the religious shades of divine light or heretical darkness, the sophistication of debate seems extraordinary. And this was largely due to the highly sophisticated reflection on the offices and duties of bishops and their subordinates, in steps that sometimes complemented and sometimes contradicted each other, and eventually produced certain, well-trodden paths.

In the end, one might say that outside of the escalating controversies like the debate on predestination, the interaction between scholars and bishops in Carolingian Francia sometimes resembles nothing so much as a somewhat ponderous, but elegant and very expressive dance. There were complicated figures and gestures, and obligatory bows and scrapes in fixed places. But altogether, both office-holders and experts managed to establish a pattern, and eventually created a flexible structure in a world that would otherwise have been quite rigid.

\section{Bibliography \\ Primary Sources}

Alcuin, Contra epistolam sibi ab Elipando directam libri quatuor, ed. by JeanPaul Migne, Patrologia Latina 101 (Paris: J.-P. Migne, 1851), cols. 231-71.

Alcuin, Epistolae, ed. by Ernst Dümmler, Monumenta Germaniae Historica, Epistolae 4, Epistolae karolini aevi II (Berlin: Weidmann, 1895), pp. 18-481.

Amulo of Lyon, Epistola 2, Monumenta Germaniae Historica, Epistolae 5, Epistolae karolini aevi III (Berlin: Weidmann, 1899), p. 377.

Iohannis Scotti seu Erivgenae Periphyseon. Liber Quintus, ed. by Edouard A. Jeauneau, Corpus Christianorum, Continuatio Mediaevalis (CCCM), 165 (Turnhout: Brepols, 2003).

Hincmar of Reims, De praedestinatione, ed. by Jean-Paul Migne, Patrologia Latina 125, (Paris: J.-P. Migne, 1959), cols. 49-473.

Otfried of Weissenburg, Epistola 19, Monumenta Germaniae Historica, Epistolae 6, Epistolae karolini aevi IV (Berlin: Weidmann, 1925), p. 169.

\footnotetext{
${ }^{60}$ See Gerd Althoff, 'Colloquium familiare -- colloquium secretum -- colloquium publicum: Beratung im politischen Leben des früheren Mittelalters', in Idem, Spielregeln der Politik im Mittelalter. Kommunikation in Frieden und Fehde (Darmstadt: Primus, 1997), pp. 157-85, first published 1990.
} 
Prudentius of Troyes, De Praedestinatione contra Johannem Scotum [...] Liber, ed. by Jean-Paul Migne, Patrologia Latina 115, (Paris: J.-P. Migne, 1859), cols. 1009-1366.

Rabanus Maurus, De institutione clericorum: Über die Unterweisung der Geistlichen, ed. and trans. into Germany by Detlev Zimpel, Fontes Christiani, 61, 2 vols (Turnhout: Brepols, 2006).

Rabanus Maurus, Epistolae, ed. by Ernst Dümmler, Monumenta Germaniae Historica, Epistolae 5, Epistolae karolini aevi III (Berlin: Weidmann, 1899), pp. 379-516.

Ratramnus of Corbie, Epistola 9, Monumenta Germaniae Historica, Epistolae 6, Epistolae karolini aevi IV (Berlin: Weidmann, 1925), p. 151.

Rudolf of Fulda, Vita Leobae abbatissae Biscofesheimensis auctore Rudolfo Fuldensi, ed. by Georg Waitz, Monumenta Germaniae Historica, Scriptores 15.1 (Hannover: Weidmann, 1887), pp. 118-31.

\section{Secondary works}

Airlie, Stuart, Pohl, Walter and Reimitz, Helmut (Eds), Staat im frühen Mittelalter, Forschungen zur Geschichte des Mittelalters, 11/ Österreichische Akademie der Wissenschaften Philosophisch-historische Klasse, Denkschriften, 334 (Vienna: Österreichische Akademie der Wissenschaften, 2006).

Althoff, Gerd, 'Colloquium familiare -- colloquium secretum -- colloquium publicum: Beratung im politischen Leben des früheren Mittelalters', in Idem, Spielregeln der Politik im Mittelalter. Kommunikation in Frieden und Fehde (Darmstadt: Primus, 1997), pp. 157-85 (first published 1990).

Bezner, Frank, Vela Veritatis: Hermeneutik, Wissen und Sprache in der 'Intellectual History' des 12. Jahrhunderts, Studien und Texte zur Geistesgeschichte des Mittelalters, 85 (Leiden: Brill, 2005).

Bianchi, Luca, Censure et liberté intellectuelle à l'université de Paris (XII-XIV Siècles), (Paris: Les Belles Lettres, 1999).

Bumke, Joachim, Courtly Culture: Literature and Society in the High Middle Ages, trans. by Thomas Dunlap, (Berkeley: University of California Press, 1991); (first published in German, 1986).

Cavadini, John C., The Last Christology of the West: Adoptionism in Spain and Gaul, 785-820 (Philadelphia: University of Pennsylvania Press, 1993).

Chazelle, Celia, The Crucified God in the Carolingian Era: Theology and the Art of Christ's Passion (Cambridge: Cambridge University Press, 2001).

Congar, Yves, 'Bref historique des formes du "magistère" et de ses relations avec les docteurs', Revue des sciences philosophiques et théologiques, 60 (1976), 99112; reprint in Idem, Droit ancien et structures ecclésiales, Variorum Collected Studies, 159 (London: Ashgate Variorum reprints, 1982), VII.

Cristiani, Marta, 'Le vocabulaire de l'enseignement dans la correspondance d'Alcuin', in Vocabulaire des écoles et des méthodes d'enseignement au moyen âge. Actes du colloque, Rome, 21-22 Oct. 1989, ed. by Olga Weijers, Civicima: Etudes sur le vocabulaire intellectuel du moyen âge, 5 (Turnhout: Brepols, 1992), pp. 13-32.

Curta, Florin, 'Merovingian and Carolingian Gift Giving', Speculum, 81 (2006), 671-99.

Davies, Wendy and Fouracre, Paul (Eds), The Languages of the Gift in the Early Middle Ages, (Cambridge: Cambridge University Press, 2010).

Curtius, Ernst Robert, European Literature and the Latin Middle Ages, trans. by Willard R. Trask, Bollingen Series, 36 (Princeton: Princeton University Press, 1991); (orig. German 1948). 
De Jong, Mayke, 'Old Law and New-Found Power: Hrabanus Maurus and the Old Testament', in Centres of Learning: Learning and Location in Pre-Modern Europe and the near East, ed. by Jan W. Drijvers and Alasdair A. MacDonald, Studies in Intellectual History, 61 (Leiden: Brill, 1995).

De Jong, Mayke, 'The empire as ecclesia: Hrabanus Maurus and biblical historia for rulers', in The Uses of the Past in the Early Middle Ages, ed. by Yitzhak Hen and Matthew Innes (Cambridge: Cambridge University Press, 2000), pp. 191226.

De Jong, Mayke, The Penitential State. Authority and Atonement in the Age of Louis the Pious, 814-840 (Cambridge: Cambridge University Press, 2009).

Depreux, Philippe, 'Ambitions et limites des réformes culturelles à l'époque carolingienne', Revue historique, 307 (2002), 721-53.

Eisenstadt, Shmuel N. and Roniger, Luis, Patrons, Clients and Friends: Interpersonal Relations and the Structure of Trust in Society (Cambridge: Cambridge University Press, 1984).

Evans, Gillian R., Getting it Wrong: The Medieval Epistemology of Error, Studien und Texte zur Geistesgeschichte des Mittelalters, 63 (Leiden: Brill, 1998).

Evans, Gillian R., Old Arts and New Theology: the Beginnings of Theology as an Academic Discipline (Oxford: Clarendon Press, 1980).

Evans, Gillian R., 'Sententia', in Latin Culture in the Eleventh Century. Proceedings of the Third International Conference on Medieval Latin Studies, Cambridge, Sept. 9-12, 1988, ed. by Herren, Michael W., McDonough, C. J. and Arthur, Ross G., Publications of the Journal of Medieval Latin, 5, 2 vols (Turnhout: Brepols, 2002), I, pp. 315-23.

Flahiff, G. B., 'Ecclesiastical Censorship of Books in the Twelfth century', Mediaeval Studies, 4 (1942), 1-22.

Ganz, David, 'The Debate on Predestination', in Charles the Bald. Court and Kingdom, ed. by Margaret T. Gibson and Janet L. Nelson, 2nd ed (Aldershot: Variorum, 1990), pp. 283-302.

Ganz, David, 'Theology and the organisation of thought', in The New Cambridge Medieval History: c. 700-900, ed. by McKitterick, Rosamond, 7 vols (Cambridge: Cambridge University Press, 1995), II, pp. 758-85.

Godman, Peter, The Silent Masters. Latin Literature and its Censors in the High Middle Ages (Princeton: Princeton University Press, 2000).

Janson, Tore, Latin Prose Prefaces: Studies in Literary Conventions, Studia Latina Stockholmensia, 13 (Stockholm: Almqvist \& Wiksell, 1964).

Hilgers, Joseph, Die Bücherverbote in Papstbriefen. Kanonistischbibliographische Studie (Freiburg: Herder, 1907).

Kottje, Raymund and Zimmermann, Harald (Eds), Hrabanus Maurus: Lehrer, Abt und Bischof, Akademie der Wissenschaften und der Literatur: Abhandlungen der Geistes- und Sozialwissenschaftlichen Klasse, 4 (Mainz: Akademie der Wissenschaften und der Literatur, 1982).

Meier, Christel, 'Autorschaft im 12. Jahrhundert: Persönliche Identität und Rollenkonstrukt', in Unverwechselbarkeit. Persönliche Identität und Identifikation in der vormodernen Gesellschaft, ed. by Peter von Moos, Norm und Struktur, 23 (Cologne: Böhlau, 2004), pp. 207-66.

Melve, Leidulf, Inventing the Public Sphere: The Public Debate during the Investiture Contest (c. 1030-1122), Studies in Intellectual History, 154, 2 vols (Leiden: Brill, 2007). 
Patzold, Steffen, Episcopus: Wissen über Bischöfe im Frankenreich des späten 8. bis frühen 10. Jahrhunderts, Mittelalter-Forschungen, 25 (Ostfildern: Thorbecke, 2008).

Piron, Sylvain, 'Ecrire en Aveugle: Jean de Roquetaillade ou la Dissidence par l'Obéissance', in Autorität und Wahrheit: Kirchliche Vorstellungen, Normen und Verfahren (13. bis 15. Jahrhundert), ed. by Gian Luca Potestà, Schriften des Historischen Kollegs, 84 (München: Oldenbourg, 2012), pp. 91-111.

Simon, Gertrud, 'Untersuchungen zur Topik der Widmungsbriefe mittelalterlicher Geschichtsschreiber bis zum Ende des 12. Jahrhunderts', Archiv für Diplomatik, 4 (1958), 52-119 [part 1] and Archiv für Diplomatik, 5/6 (195960), 73-153 [part 2].

Speyer, Wolfgang, Büchervernichtung und Zensur des Geistes bei Heiden, Juden und Christen, Bibliothek des Buchwesens, 7 (Stuttgart: Hiersemann, 1981).

Steckel, Sita, 'Ammirabile commertium. Die Widmungen des Hrabanus Maurus und andere symbolische Geschenke als Gaben im Angesicht Gottes', in Geschenke erhalten die Freundschaft. Gabentausch und Netzwerkpflege im europäischen Mittelalter. Akten des Internationalen Kolloquiums Münster, 19-20 November 2009, ed. by Michael Grünbart, Byzantinistische Studien und Texte, 1 (Münster: Lit, 2011), pp. 209-49.

Steckel, Sita, Kulturen des Lehrens im Früh- und Hochmittelalter. Autorität, Wissenskonzepte und Netzwerke von Gelehrten, Norm und Struktur, 39, (Cologne, Vienna: Böhlau, 2011).

Somerville, Robert, 'Pope Nicholas I. and John Scottus Eriugena: JE 2833', Zeitschrift der Savigny-Stiftung für Rechtsgeschichte -- Kanonistische Abteilung, 114 (1997), 67-85.

Vollrath, Hanna, 'Bernhard und Abaelard. Ein Beispiel für die Entstehung von Zensur in einer Umbruchsituation', in Kanon und Zensur, ed. by Aleida and Jan Assmann, Beiträge zur Archäologie der literarischen Kommunikation, 2 (Munich: Fink, 1987), pp. 309-316.

Werner, Thomas, Den Irrtum liquidieren. Bücherverbrennungen im Mittelalter (Göttingen: Vandenhoeck \& Ruprecht, 2007).

Wiest, Donald H., The Precensorship of Books. Canons 1384-1386, 1392-1394, 2318 \& 2. A History and a Commentary, Canon Law Studies, 329 (Washington D.C.: Catholic University of America Press, 1953). 